\title{
A review of biostratigraphical investigations of palaeolithic localities in the Southern Urals region
}

\author{
Guzel Danukalova*, Anatoly Yakovlev \\ Institute of Geology, Ufa Scientific Centre, Russian Academy of Sciences, K. Marx St., 16/2, 450000 Ufa-Centre, Bashkortostan, Russian Federation
}

Available online 20 January 2006

\begin{abstract}
At present there are more than 15 Palaeolithic type localities in the Southern Urals region. Most of these are located in karst cavities in the mountain area. In the flat part of the country, Palaeolithic type localities are extremely rare and are situated in the deposits of the second river terraces. Results of biostratigraphical investigations of the main localities are given in this short review.

(C) 2005 Elsevier Ltd and INQUA. All rights reserved.
\end{abstract}

\section{Introduction}

The territory referred to here is located in the Fore-Urals border depression area and in the Southern Urals (Russian Federation). Palaeolithic localities have been described and investigated in the Southern Urals region from the second part of the 19th century. At present more than 15 localities are known, most of which are located in the mountain area in karst cavities: Shulgan-Tash (Kapova), Kuljurt-Tamak, Ignatievskaya, Serpievskaya 2, Muradymovskaya 2, etc. In the flat part of the country, Palaeolithic type localities are extremely rare (Gornova, Novobelokatai) and are situated in the deposits of the second river terraces. Artefacts are not numerous in these localities.

Results of biostratigraphical studies of the main sections have been given in short reviews (see Bader, 1965, 1971; Shchelinsky, 1989, 1997; Shokurov and Bader, 1960; Smirnov et al., 1990; Yakhimovich, 1965). Palaeolithic type localities (Zapovednaya cave, Bajslan-Tash cave, Novobelokatai, and Gornova) in the Bashkortostan Republic have been investigated by the Institute of Geology, Ufa Scientific Centre, Russian Academy of Sciences. The sections described below are shown in Fig. 1.

\footnotetext{
${ }^{*}$ Corresponding author.

E-mail address: danukalova@anrb.ru (G. Danukalova).
}

\section{Methods}

All terraces and a small part of the type localities of Palaeolithic caves have been biostratigraphically studied. Palynological investigations were done for deposits with cultural layers in the cave localities Shulgan-Tash, Ignatievskaya, and Serpievskaya 2. Palaeozoological investigations (mammalian faunas) were carried out in all cave localities, and radiocarbon dates were obtained from some cave localities.

\section{Cave localities}

\subsection{Serpievskaya 2 cave}

The cave, on the western slope of the Southern Urals (upper reaches of the Sim River), was investigated by Petrin et al. (1986) (Shirokov and Kosintcev, 1997; Smirnov et al., 1990). The excavation in the cave was situated $50 \mathrm{~m}$ from the cave entrance. Deposits are represented by reworked deposits $(0.1 \mathrm{~m})$, light loam $(0.1-0.15 \mathrm{~m})$, and reddish-brown clay with ash in the upper part of the layer $(0.3 \mathrm{~m})$. Cave paintings depict signs, as well as a fragment of animal bone (deer?) painted with red ochre.

The species composition of the mammals from different layers is similar. Small mammal remains of Microtus gregalis, Lagurus lagurus, M. oeconomus from layer 2 with 


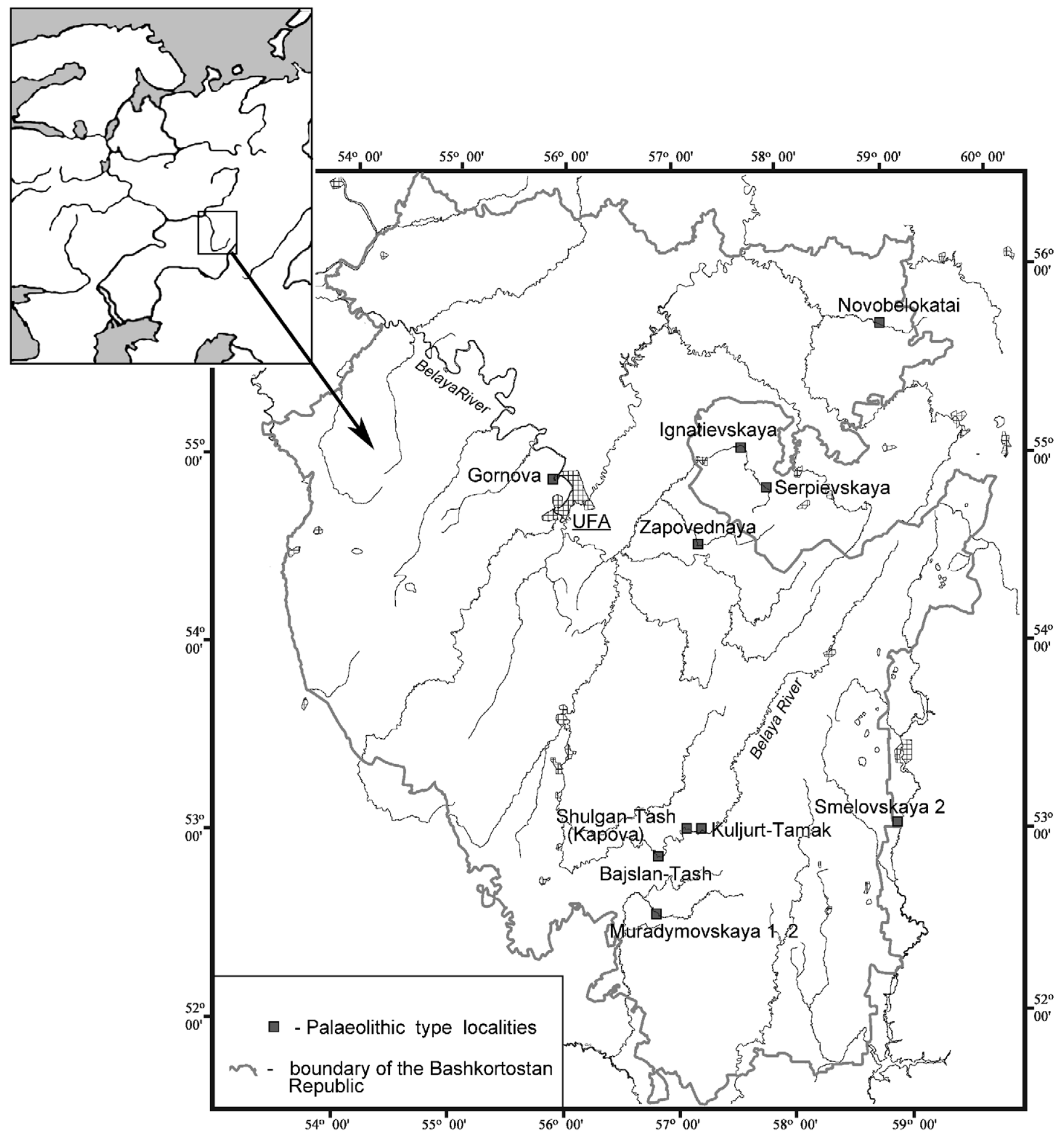

Fig. 1. Map showing the main Palaeolithic localities.

ash predominated. Bones were identified of Dicrostonyx guilielmi, Arvicola terrestris, M. arvalis, M. agrestis, Ochotona sp., Citellus superciliosus, Sicista sp., Cricetus cricetus, Cricetulus migratorius, Allocricetulus eversmanni Brandt, and Lemmus sibiricus. Remains of Lepus sp. are numerous. Bones of Vulpes vulpes, Canis lupus, Spelaearctos spelaeus, Marmota bobac, Alopex lagopus, Mustela erminea, M. nivalis, Mustela sp., Crocuta spelaea, Equus sp., Coelodonta antiquitatis, Rangifer tarandus, Alces alces, Saiga tatarica are rare. The vegetation consisted of meadow-steppe associations with small Picea forests in the beginning of the Ostashkovo phase during sedimentation of the cultural layer. Bones 
from a depth of $30-40 \mathrm{~cm}$ are ${ }^{14} \mathrm{C}$ dated to $25,200 \pm 1800$ (IERZH-46).

\subsection{Ignatievskaya cave}

In Petrin et al. (1980) found Palaeolithic cave paintings in this cave, located on the western slope of the Southern Urals (upper reaches of the Sim River). Archaeologists and palaeobiologists studied the cave in 1980-1986 (Shirokov and Kosintcev, 1997; Smirnov et al., 1990).

Sediments $(1.9 \mathrm{~m}$ thick) were excavated deep into the cave. The cultural layer is located $0.1-0.35 \mathrm{~cm}$ above the base of the cave. Cave paintings in the form of signs (such as dots, groups of triangles and parallelograms), animals (mammoth, rhinoceros, camel, horse and bison), and anthropomorphic creatures, and 1350 stone artefacts were found. Adornments with polar fox teeth, beads, stone implements and pieces of ochre were discovered.

The mammalian fauna is of Upper Palaeolithic age. Remains of $M$. gregalis predominated, while bones of D. guilielmi, C. migratorius, L. lagurus, and Eolagurus luteus were present. Bones of large mammals were not numerous and came from $S$. spelaeus, Lepus sp., M. bobac, A. lagopus, V. vulpes, M. nivalis, Equus sp., C. lupus, Putorius sp., M. erminea, C. spelaea, Bos or Bison, and $S$. tatarica. In the Ostashkovo phase, during sedimentation of the cultural layer, periglacial steppe with elements of tundra and shrub associations predominated.

Bones from a depth of $5-55 \mathrm{~cm}$ are ${ }^{14} \mathrm{C}$ dated to $14,038 \pm 490$ (IEMEZG-366) and 13,500 \pm 1660 (IERZG-41). Ash from the cultural layer is ${ }^{14} \mathrm{C}$ dated to $14,240 \pm 150$ (SOAN-2209), 13,335 \pm 192 (IEMEZG-365), and 10,400 \pm 465 (SOAN-2468).

\subsection{Shulgan-Tash (Kapova) cave}

Located on the western slope of the Southern Urals (middle reaches of the Belaya River), the cave was discovered by Ryumin (1959) and studied by Bader (1965), Shchelinsky (1989, 1997), Kuzmina and Abramson (1997), and others.

Excavations were carried out deep into the cave. The unconsolidated deposits measured nearly $2.1 \mathrm{~m}$. The cultural layer $(0.02-0.12 \mathrm{~m})$ is located at a depth of $50 \mathrm{~cm}$ from the bottom of the cave and consisted of gray and dark-gray loam with ash and ochre.

More than 50 cave paintings of animals (mammoth, horse, rhinoceros, bison), zoo-anthropomorphic creatures and trapezium signs were discovered. A total of 193 stone artefacts, 3 pebble implements, 7 bone adornments, 17 beads and pendants, a clay lamp, and ochre were found.

Bone remains of mammoth, S. spelaeus, Lepus sp., V. vulpes, A. lagopus, M. bobac, Ochotona sp., Allactaga major, D. torquatus, L. lagurus, M. gregalis, M. arvalis, C. migratorius are present but not numerous. In the Ostashkovo phase near the cave, grassland with Carex- tussocks steppe with rare Picea, Pinus, Betula, Larix, and Juniperus existed. Ash from the cultural layer is ${ }^{14} \mathrm{C}$ dated to $14,680 \pm 150(\mathrm{LE}-3434)$ and $13,930 \pm 490$ (GIN-4853).

\subsection{Kuljurt-Tamak cave}

This cave, on the western slope of the Southern Urals (middle reaches of the Belaya River), was studied by Bader (1965), and P.E. Nekhoroshev, I.E. Kuzmina, and A.G. Yakovlev (Nekhoroshev, 1997). The thickness of the studied unconsolidated deposits is nearly $5.7 \mathrm{~m}$. The sediments are represented by soil $(2 \mathrm{~m})$, gray-brown loam $(0.1-0.3 \mathrm{~m})$, gray-yellow loam $(0.8 \mathrm{~m})$, light-brown loam $(2.2 \mathrm{~m})$, dark-gray loam $(0.2 \mathrm{~m})$, and red-brown loam with pebbles, and sand in the lower part of the layer $(2 \mathrm{~m})$. The cultural layer has a thickness of $60 \mathrm{~cm}$, and is located at a depth of 1.0-2.5 m from the bottom of the cave. A total of 348 stone artefacts were found.

The large mammals are represented by Mammuthus primigenius, C. antiquitatis, Panthera spelaea, Bison sp., and A. lagopus. Remains of Dicrostonyx sp., Lepus sp., M. bobac, Spermophilus sp., Allactaga major, Ellobius sp., Clethrionomys rutilus, Ochotona sp., L. lagurus, M. gregalis and $M$. oeconomus were determined from the cultural layer. Ash from the cultural layer has been ${ }^{14} \mathrm{C}$ dated to $14,920 \pm 660$ (LE-4350) and 15,870 \pm 390 (LE-3350).

\subsection{Muradymovskaya 2 cave}

At this cave, located on the western slope of the Southern Urals (middle reaches of the Ik River), biostratigraphical investigations were not carried out. Eleven cave pictures of anthropomorphic creatures done in red paint are known (Shirokov and Kosintcev, 1997).

\subsection{Smelovskaya 2 cave}

This cave is located on the eastern slope of the Southern Urals (Small Kizil River). It was studied by K.V. Salnikov in 1950, Bader in 1962 and 1965 (Bader, 1971), and Kuzmina (2000). The thickness of unconsolidated deposits is $2.38 \mathrm{~m}$. The deposits consist of yellow loam, brown loam with bones, ash, artefacts, yellow loam with bones, stone implements, and sandy clay with bones. In layers 3-4 flint artefacts and ash were discovered, and in layers 1-2 Mesolithic flint pendants.

Layers 3-4 contain Palaeolithic mammal remains: Equus cf. latipes, M. bobac, C. lupus, V. vulpes, C. spelaea, S. spelaeus, C. antiquitatis, Bison priscus, S. tatarica, Equus hydruntinus, M. primigenius, P. spelaea, A. lagopus, and Lepus tanaiticus. In layers 1-2 mammal bones of Holocene age were discovered. Horse bones from layers 3-4 have been ${ }^{14} \mathrm{C}$ dated to $31,000 \pm 1500(\mathrm{GIN}-8401)$, and a mammoth bone is ${ }^{14} \mathrm{C}$ dated to $41,000 \pm 1800$ (GIN-8402) and 25,000 \pm 600 (GIN—8403). 


\subsection{Zapovednaya cave}

On the western slope of the Southern Urals (middle reaches of the Lemeza River), this cave was discovered in 1969 by V.A. Marushin and then studied by V.A. Morozov in 1983, V.K. Fedorov in 1995, and V.G. Kotov (1997). Biostratigraphical investigations were carried out by scientists of the Institute of Geology (Ufa) in 1995-1996 (Alimbekova et al., 1998).

Unconsolidated eluvial-deluvial deposits ( $1 \mathrm{~m}$ thick) are represented by yellow-brown and brown loam with bone remains of $S$. spelaeus (Fig. 2). The cave contains a unique construction of cave bear skulls that probably represents a cult of Palaeolithic hunters. Bone remains of $S$. spelaeus predominated. M. bobac, V. vulpes, and C. lupus were determined. Reptilia and Amphibia are present among the bone remains (Rana temporaria, Bufo bufo, Anguis fragilis, Lacerta vivipara, and Vipera berus). In the Leningrad phase, mixed leaf-coniferous forests with broad-leaved trees were present in this area, while in the Ostashkovo phase forest-steppe associations predominated. Ash from the upper part of this section is ${ }^{14} \mathrm{C}$ dated to $12,380 \pm 260$ (LU-3861), and bones of cave bear are ${ }^{14} \mathrm{C}$ dated to $28,700 \pm 1000(\mathrm{LU}-3715)$ and 37,250 (LU-3876).

\subsection{Bajslan-tash cave}

The cave, in the Southern Urals (middle reaches of the Belaya River), was discovered by I.I. Lepekhin in 1870 . Archaeological excavations were carried out by M.F. Obydennov in 1997, and V.G. Kotov in 1999-2001. Biostratigraphical investigations were provided by scientists of the Institute of Geology (Ufa) in 1999-2001 (Fig. 3). Unconsolidated eluvial-deluvial deposits ( $3 \mathrm{~m}$ thick) consist of dark-gray loam (layers 1-2, Late Holocene), and brown loam (layer 3, Middle Holocene, and layer 4, Late Pleistocene) are present. In layer 4, artefacts of the latest Palaeolithic were discovered.

Terrestrial and freshwater molluscs were found in these deposits. Large mammals in layer 4 are represented by Lepus sp., M. nivalis, M. erminea, Martes martes, Capreolus capreolus, Ovis aries, Marmota sp., Castor fiber, $R$. tarandus, C. lepus, and $V$. vulpes. And small mammals by $M$. gregalis, L. lagurus, Ochotona sp., M. oeconomus, Sorex sp., M. agrestis, Clethrionomys ex gr. glareolusrutilus, M. arvalis, Apodemus ex gr. uralensis-agrarius, C. cricetus, A. terrestris, Chiroptera, A. eversmanni, Apodemus uralensis, Ellobius sp., Spermophilus sp., Crocidura sp., Sicista sp., Talpa sp., Erinaceus sp., Apodemus

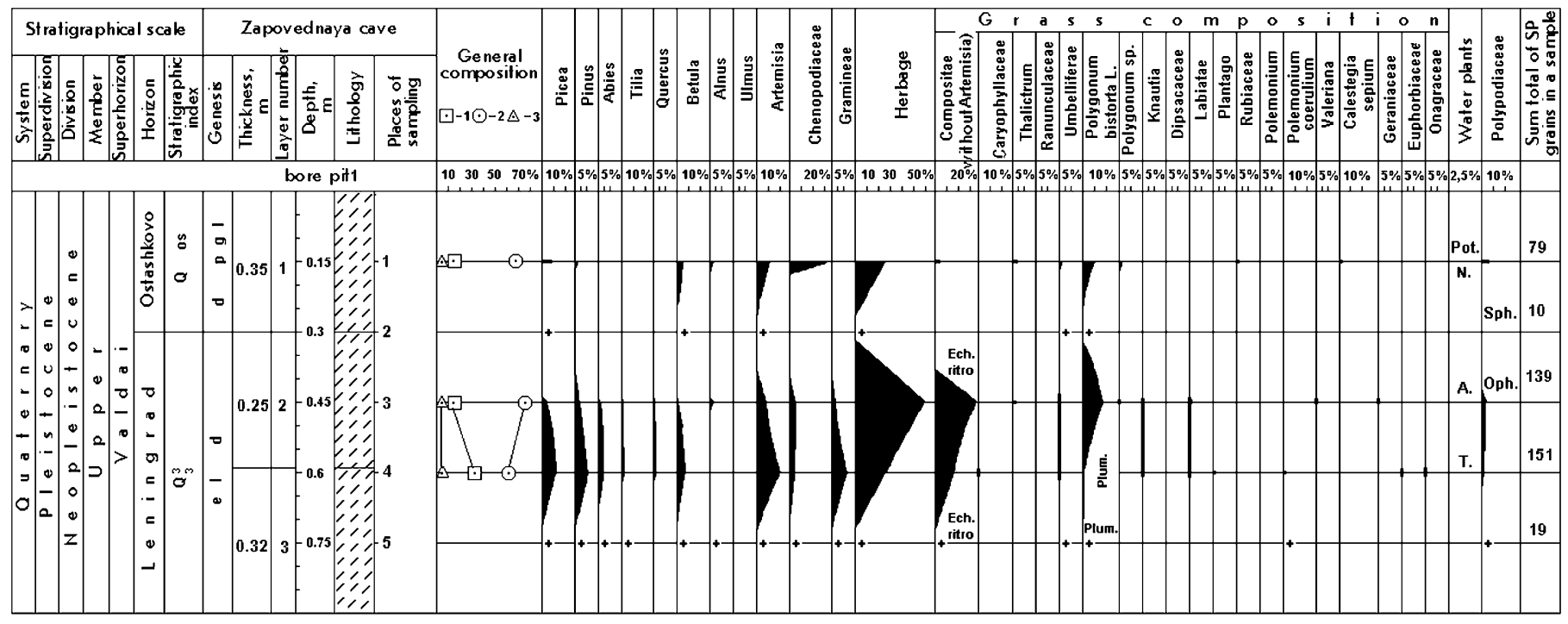

1. $\square$ - trees 2. $\odot$ - grass 3. $\Delta-$ sporophytes 617 - bam

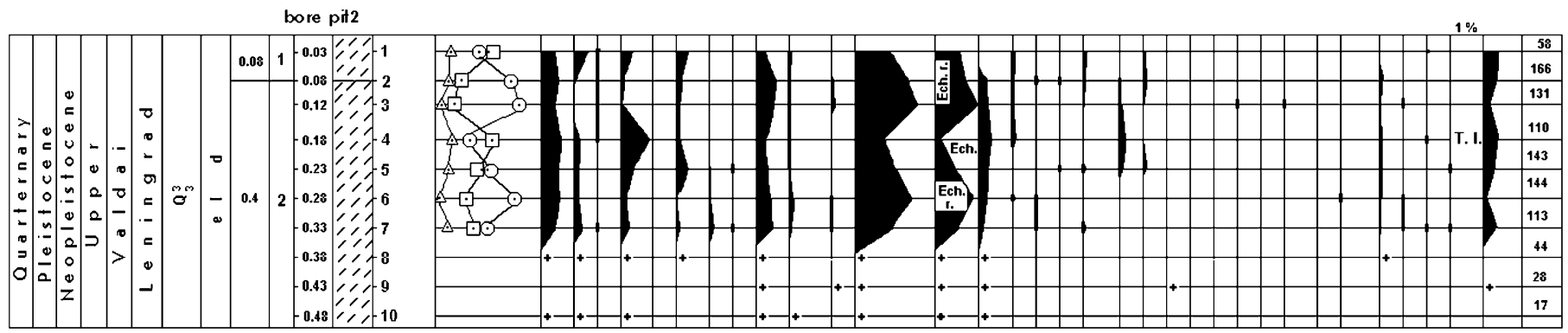

Fig. 2. Zapovednaya cave. Deposits and percentage pollen curves of the main taxa from the interval Upper Pleistocene-Holocene (after R. Sataev, A. Yakovlev, and L. Alimbekova). 


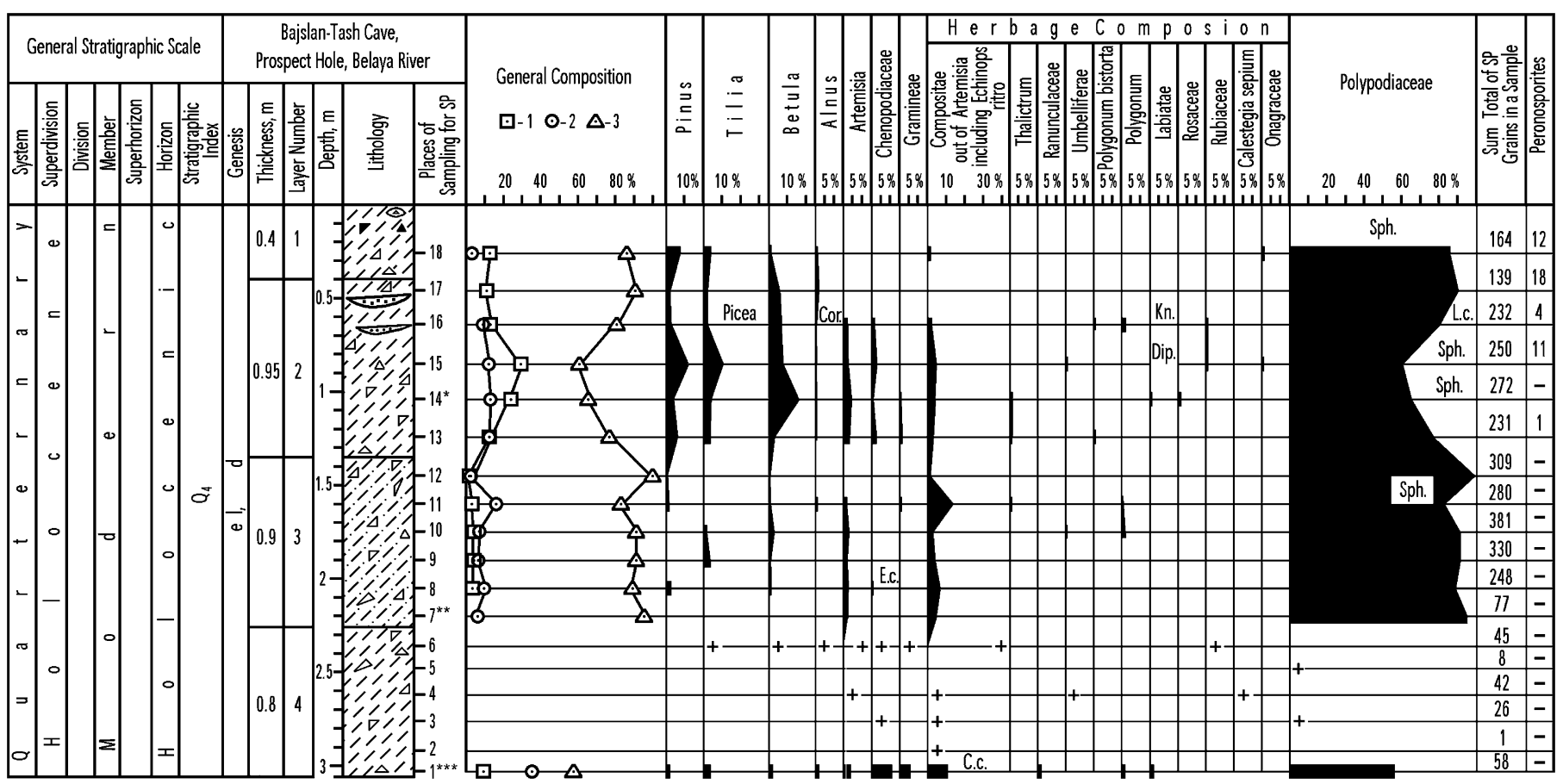

Fig. 3. Bajslan-Tash cave. Deposits and percentage pollen curves of the main taxa from the interval Upper Pleistocene-Holocene (after G. Danukalova, A. Yakovlev, and L. Alimbekova).

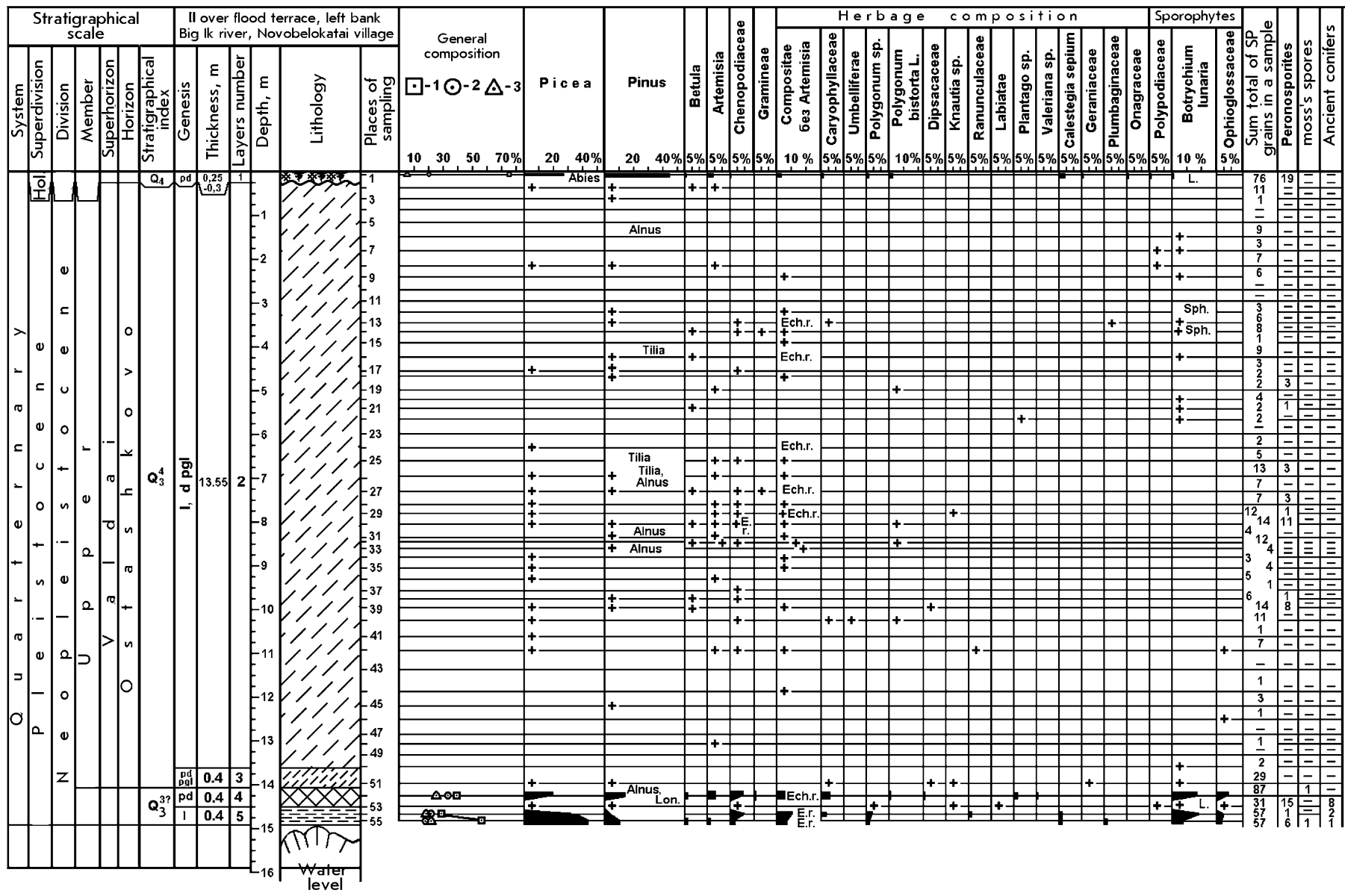

Fig. 4. Novobelokatay locality. Deposits and percentage pollen curves of the main taxa from the Upper Pleistocene (after G. Danukalova and L. Alimbekova). 
flavicollis, C. migratorius, C. rufocanus, and E. luteus. Towards the end of the Ostashkovo phase, meadow-steppe associations predominated with small Betula and Tilia forests. Bones of small mammals from the cultural layer have been ${ }^{14} \mathrm{C}$ dated to $13,560 \pm 250(\mathrm{GIN}-10853)$.

\section{Flat countryside localities}

\subsection{Novobelokatai}

Novobelokatai, in the northern part of the Southern Fore-Urals (Large Ik River, Novobelokatai settlement), was studied by K.V. Salnikov in 1964, and V.G. Kotov, G.A. Danukalova, A.G. Yakovlev and others in 1995-1996 (Danukalova et al., 2000) (Fig. 4). The cultural layer consisting of lacustrine-moor clay is located in the lower part of the river terrace under $15 \mathrm{~m}$ thick Ostashkovo loams. Archaeological stone and bone implements of Mousterian age were collected from the deposits of the cultural layer.

Bone remains of B. priscus, Equus sp., M. primigenius, C. antiquitatis, Megaloceros giganteus, and Cervus elaphus were determined from this layer. Freshwater molluscs were also found in these deposits. In the Leningrad phase, forest-steppe associations with mixed forests predominated in this region. Ash from the cultural layer has been ${ }^{14} \mathrm{C}$ dated to $41,070 \pm 1570$ (LU-4149).

\subsection{Gornova}

Gornova, in the northern part of the Southern ForeUrals (lower reaches of the Belaya River, near Gornova village in the surroundings of Ufa), was discovered by A.P. Shokurov in 1959. Archaeologically this locality was studied by Shokurov and Bader (1960) and Sherbakova (1984). Deposits of the second terrace were described and investigated by V.L. Yakhimovich, G.A. Danukalova, A.G. Yakovlev and others (Yakhimovich, 1965; Yakhimovich et al., 1987; Fig. 5).

The terrace deposits measure $15.4 \mathrm{~m}$. The cultural layer ( $3 \mathrm{~m}$ thick) consists of lacustrine clay (Leningrad phase) and is located in the middle part of the river terrace under the brown loams of Ostashkovo time. Archaeological occurrences (8 flint implements) are of Late Mousterian age.

Large mammals of Upper Palaeolithic age were discovered in the deposits: B. priscus gigas, B. priscus, Bison sp., Alces cf. alces, and E. caballus fossilis (by B.S. Kozhamkulova). From the upper part of this unit small

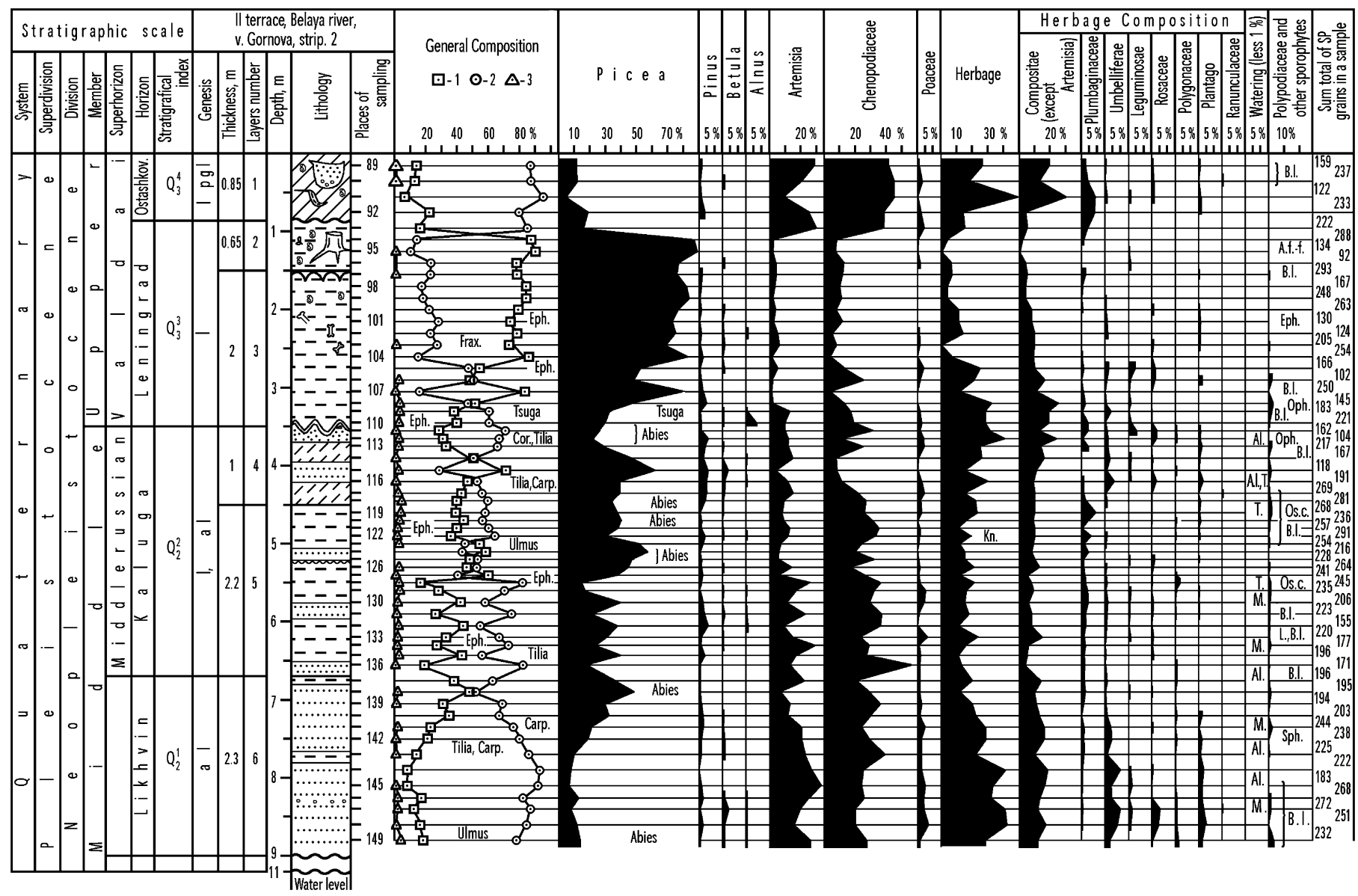

Fig. 5. Gornova locality. Deposits and percentage pollen curves of the main taxa from the interval Middle - Upper Pleistocene (after G. Danukalova and L. Alimbekova). 
mammals remains were determined: Sorex sp., Citellus sp., A. eversmanni, C. rufocanus, L. lagurus, Lagurus sp., E. luteus, M. gregalis, M. oeconomus, and Microtus sp. Terrestrial and freshwater molluscs were found in all deposits. In the Leningrad phase, steppe predominated in this region, with woods of coniferous trees in the river valleys.

Stumps of Picea and Pinus from the layer under the loams are ${ }^{14} \mathrm{C}$ dated to $21,280 \pm 550$ (LE-145), $22,660 \pm 125$ (BashGI-35), 28,800 \pm 124 (BashGI-36), $29,700 \pm 1250(\mathrm{H}$ 1856/1287), 26,950 \pm 560 (LU-3711), and $26,990 \pm 150$ (LU-3712). Bison sp. Bone from the cultural layer has been ${ }^{14} \mathrm{C}$ dated to $\geqslant 33,670(\mathrm{LU}-4153)$.

\section{Conclusions}

The number of known Palaeolithic localities in the Southern Urals region is not very large: 2 are located in the Fore-Urals, and 6 localities are in Ural caves (5 of which situated on the western slope of the Urals). The study of fauna and flora remains has helped to reconstruct palaeoenvironments of Palaeolithic age in the Southern Urals region. The application of complex biostratigraphical methods is required for a detailed reconstruction. It is necessary to investigate not only the cultural layer but also the adjacent deposits. Radiocarbon studies provided more detailed dates for the different events of the last geological periods.

\section{References}

Alimbekova, L.I., Danukalova, G.A., Epifanova, M.S., 1998. Results of a study of pollen-spores from the Zapovednaya cave. In: Puchkov, V.N. (Ed.), Annual report-1996. Information materials of the Institute of Geology USC, RAS, Ufa, pp. 8-12 (in Russian).

Bader, O.N., 1965. Kapovaya Cave. Palaeolithic Painting. Nauka press, Moscow 48pp (in Russian).

Bader, O.N., 1971. Smelovskaya 2 Palaeolithic stand in the steppe of the Southern Urals. In: Palaeolithic and Neolithic of the USSR, 6 . Materials of the Institute of Archaeology 173, Moscow, pp. 200-209 (in Russian).

Danukalova, G.A., Yakovlev, A.G., Kotov, V.G., 2000. Age, biostratigraphy and archaeology of lacustrine deposits from the second overflood plain terraces of the Southern Fore-Urals. In: Puchkov, V.N., Kazantcev, Yu.V. (Eds.), Geological Collection N 1. Informa- tion Materials of the Institute of Geology, USC, RAS, Ufa, pp. 69-72 (in Russian).

Kotov, V.G., 1997. Tracks of the cave bear cult of the Southern Urals (data from the Zapovednaya cave). In: Cave Palaeolithic of the Urals. Materials of International Conference, Ufa, 9-15 September 1997, Print Press, pp. 42-45 (in Russian).

Kuzmina, S.A., 2000. Faunistic data of the Late Palaeolithic stand Smelovskaya 2 of the Southern Urals. In: Kosintcev, P.A. (Ed.), Pleistocene and Holocene faunas of the Urals. Riphei press, Chelyabinsk, pp. 137-153 (in Russian).

Kuzmina, I.E., Abramson, N.I., 1997. Mammal remains of the Kapovaya cave of the Southern Urals. In: Cave Palaeolithic of the Urals. Materials of International Conference, Ufa, 9-15 September 1997, Print Press, pp. 124-127 (in Russian).

Nekhoroshev, P.E., 1997. Stone industry of the cave locality KuljurtTamak (Southern Urals). In: Cave Palaeolithic of the Urals. Materials of International Conference, 9-15 September 1997, Ufa, Print press, pp. 46-50 (in Russian).

Shchelinsky, V.E., 1989. Some results of new investigations at the Kapova Cave in the Southern Urals. Proceedings of the Prehistoric Society 55, 181-191.

Shchelinsky, V.E., 1997. Palaeogeographical environment and archaeological complex of the Upper Palaeolithic sanctuary of Shulgan-Tash (Kapovaya). In: Cave Palaeolithic of the Urals. Materials of International Conference, Ufa, 9-15 September 1997. Print press, pp. 29-38 (in Russian).

Sherbakova, T.I., 1984. Modern study results of the Palaeolithic of the Southern Urals. In: Sources of the History and Culture of the Bashkortostan, Ufa. Print press, pp. 9-10 (in Russian).

Shirokov, V.N., Kosintcev, P.A., 1997. A review of the use of Ural caves in the Palaeolithic. In: Cave Palaeolithic of the Urals. Materials of International Conference, Ufa, 9-15 September 1997. Print press, pp. 26-29 (in Russian).

Shokurov, A.P., Bader, O.N., 1960. Palaeolithic locality of the Belaya river. In: Vakhrushev, G.V., Yakhimovich, V.L. (Eds.), Questions of geology of the eastern part of the Russian platform and Southern Ural 5, Ufa. Bashkirian branch of the Academy of Sciences Press, pp. 139-144 (in Russian).

Smirnov, N.G., Bolshakov, V.G., Kosintcev, P.A., Panova, N.K., Korobeinikov, Yu.I., Olshvang, V.N., Erokhin, N.G., Bykova, G.V., 1990. Historical Ecology of Animals of the Southern Urals. Urals Branch of Academy of Sciences Press, Sverdlovsk 245pp (in Russian).

Yakhimovich, V.L., 1965. Anthropogene deposits of the Southern ForeUrals. Pleistocene. In: Yakhimovich, V.L. (Ed.), Anthropogene of the Southern Urals. Nauka presa, Moscow, pp. 36-53 (in Russian).

Yakhimovich, V.L., Nemkova, V.K., Sydnev, A.V., Suleimanova, F.I., Khabibullina, G.A., Sherbakova, T.I., Yakovlev, A.G., 1987. Pleistocene section near the archaeological locality of Gornova. In: Kamaletdinov, M.A., Yakhimovich, V.L., Sydnev, A.V. (Eds.), The Pleistocene of the Fore-Urals. Nauka press, Moscow, pp. 22-50 (in Russian). 